$12-21-2021$

\title{
Collective Healing to Address Legacies of Transatlantic Slavery: Opportunities and Challenges
}

\author{
Scherto R. Gill \\ Global Humanity for Peace Institute/University of Wales Trinity St David \\ Garrett Thomson \\ Guerrand-Hermes Foundation for Peace/Wooster College
}

Follow this and additional works at: https://digitalcommons.usf.edu/gsp

\section{Recommended Citation}

Gill, Scherto R. and Thomson, Garrett (2021) "Collective Healing to Address Legacies of Transatlantic Slavery: Opportunities and Challenges," Genocide Studies and Prevention: An International Journal: Vol. 15: Iss. 3: $49-65$.

DOI:

https://doi.org/10.5038/1911-9933.15.3.1877

Available at: https://digitalcommons.usf.edu/gsp/vol15/iss3/9

This Articles is brought to you for free and open access by the Open Access Journals at Digital Commons @ University of South Florida. It has been accepted for inclusion in Genocide Studies and Prevention: An International Journal by an authorized editor of Digital Commons @ University of South Florida. For more information, please contact digitalcommons@usf.edu. 


\title{
Collective Healing to Address Legacies of Transatlantic Slavery: Opportunities and Challenges
}

\author{
Scherto R. Gill \\ Global Humanity For Peace Institute \\ University of Wales Trinity Saint David \\ Guerrand-Hermès Foundation for Peace
}

Garrett Thomson

College of Wooster; Guerrand-Hermès

Foundation for Peace Research Institute

\begin{abstract}
Introduction ${ }^{1}$
Between the 16th and 19th centuries, approximately 28 million African men and women were captured, enslaved, or perished during transit in Africa, the Americas, and the Caribbean. ${ }^{2}$ These events, referred to by some Africans as the Maafa, ${ }^{3}$ is one of the longest and most extensive mass atrocities in human history. The harmful effects of these events have continued today as unhealed trauma, transmitted from one generation to the next, sustained through structural dehumanization. ${ }^{4}$ This trauma has had significant impact not only on Africans and the African diasporas, ${ }^{5}$ but also on peoples of European descent and on interpersonal and intercommunal dynamics in contemporary western societies.

In this article, we show how pathways to justice and reconciliation pertaining to transatlantic slavery should begin with collective healing processes. To illustrate this conclusion, we first employ a four-fold conceptual framework to understand collective healing that consists in: (1) acknowledging historical dehumanizing acts; (2) addressing the harmful effects of dehumanization; (3) embracing relational rapprochement; and (4) coimagining and co-creating conditions for systemic justice. ${ }^{6}$ Based on this framework, we then examine existing collective healing practices in different contexts that are aimed at addressing legacies of transatlantic slavery. In doing so, we further identify challenges and pose critical questions concerning such practices. While globally there are, and have been, many kinds of racism and slavery, and even though transatlantic slavery has many features specific to it, nevertheless, we hope that this exploration of collective healing will be illuminating for other situations where acts of brutality have served to demean and dehumanize.
\end{abstract}

\section{A Four-Fold Framework for Collective Healing}

In this section, we briefly sketch the conceptual framework that shapes the overall investigation of this article. As argued elsewhere, to understand healing, one needs to comprehend

\footnotetext{
1 This article is part of the GSP Special Issue 15.3 on Collective Healing. The views expressed in this article belong solely to the authors. Due to its technical nature, this article did not undergo the double-blind peer review process.

2 Paul E. Lovejoy, Transformations in Slavery: A History of Slavery in Africa, 3rd ed. (Cambridge: Cambridge University Press, 2012).

${ }^{3}$ A Kiswahili term for great trauma.

4 Na'im Akbar, Breaking the Chains of Psychological Slavery (Tallahassee: Mind Productions \& Associates, 1996); Thomas Hübl and Julie Jordan Avritt, Healing Collective Trauma: A Process for Integrating Our Intergenerational and Cultural Wounds (Boulder: Sounds True, 2020).

${ }^{5}$ Jean-Michel Deveau, “European Slave Trading in the Eighteenth Century," Diogenes 45, no. 179 (1997), 49-74.

${ }^{6}$ More details on the development of this framework can be found in Garrett Thomson piece on Collective Healing in this Special Issue. See Garrett Thomson, "Collective Healing: Towards a Conceptual Framework," Genocide Studies and Prevention 15, no. 3, 33-48, https://doi.org/10.5038/1911-9933.15.3.1843.
}

Scherto R. Gill and Garrett Thomson. "Collective Healing to Address Legacies of Transatlantic Slavery: Opportunities and Challenges." Genocide Studies and Prevention 15, no. 3, 49-65. https://doi.org/10.5038/1911-9933.15.3.1877.

(C) 2021 Genocide Studies and Prevention. 
wounding. ${ }^{7}$ For enslaved Africans, the wounding primarily consists in being treated as less than fully a person. While dehumanizing acts inflict harm on a person, such acts are pernicious independently of those other harms. Dehumanizing acts are wrong not only because they cause harm, but also primarily because they deny a person's intrinsic value or dignity. ${ }^{8}$

Historically, the brutal acts of transatlantic slavery were carried out by a variety of actors who were not only individual persons and groups, but also institutions and even the political economic system as a whole. ${ }^{9}$ The history needs to be characterized in this way because these actions were part of the expansion of capitalism. ${ }^{10}$ Through slavery and colonization, the emerging capitalist system subjected African and indigenous people to inhumane treatment for the sake of economic gain.11 In addition to physical violence, enslavement deprives the enslaved of their home, meaningful social relationships and cultural practices, and excludes them from the dignity of work. In short, it takes away a person's life in community. ${ }^{12}$ While other kinds of slavery existed beforehand and have existed since, the capitalist system made possible a new form of slavery, a systematic and industrialized dehumanization. ${ }^{13}$

Because unhealed trauma and its damaging effects can be transmitted intergenerationally, this past dehumanization will continue to fuel contemporary racism unless we come to terms with this history. ${ }^{14}$ For instance, the descendants of those who experienced trauma and those who perpetrated the harms can be locked in a psychic tomb unless they acknowledge and mourn the losses and suffering. ${ }^{15}$ Without healing, the harmful emotional contents of the historical brutalities will remain, festering within people and communities.

For this reason, it is important to briefly chart below some of the harmful effects of the trauma and wounds experienced by the descendants of formerly enslaved people that healing aims to address.

First, historical atrocities will continue to harm generations of people primarily as the experience of being treated instrumentally, in dehumanizing ways, as if they were objects. ${ }^{16}$

Secondly, this kind of dehumanizing treatment tends to scar people's emotional selfperception and self-appreciation. It can make people feel fragmented in their self-awareness, ${ }^{17}$ and such fragmentation is usually experienced as self-alienation. This tends to cause self-

7 UNESCO, Healing the Wounds of Slave Trade and Slavery. Approaches and Practices: A Desk Review, (Brighton: The UNESCO Slave Route Project / GHFP Research Institute, January 2021).

8 A more elaborated argument on this point is found in Thomson, Collective Healing.

${ }_{9}^{9}$ Garrett Thomson et al., Happiness, Flourishing and the Good Life: A Transformative Vision for Human Well-Being (London: Routledge, 2020).

${ }^{10}$ Seymour Drescher, “Capitalism and Slavery After Fifty Years," Slavery \& Abolition 18, no. 3 (2008), 212-227.

11 Robert C. Allen, The British Industrial Revolution in Global Perspective (Cambridge: Cambridge University Press, 2009); Edward E. Baptist, The Half Has Never Been Told: Slavery and the Making of American Capitalism (London: Hachette, 2016); Mark Stelzner, "Slavery and Capitalism," Labor History 61, no. 3-4, (2020), 335-347.

12 Mark Fisher, Capitalist Realism: Is There No Alternative? (Winchester: Zero Books, 2009); Thomson et al., Happiness.

${ }^{13}$ Lovejoy, Transformations in Slavery.

${ }^{14}$ Hübl and Avritt, Healing Collective Trauma; Vamik Volkan, Large-Group Psychology: Racism, Societal Divisions, Narcissistic Leaders and Who We Are Now (Oxfordshire: Phoenix, 2020); Rachael D. Goodman, "The Transgenerational Trauma and Resilience Genogram," Counselling Psychology Quarterly 26, no. 3-4 (2013), 386-405.

15 Volkan, Large-Group Psychology, 78.

16 Thomson, Collective Healing.

17 Dee Watts-Jones, "Healing Internalized Racism: The Role of a Within-Group Sanctuary Among People of African Descent," Family Process 41, no. 4 (2002), 591-601; Henry Louis Jr. Gates, Figures in Black: Words, Signs, and the "Racial" Self (Oxford: Oxford University Press, 1987). 
loathing and withdrawal in some cases, and thereby vulnerability to abuse, including negative racial stereotyping, and even ill-being. ${ }^{18}$

Furthermore, traumas are experienced as profoundly personal emotions. The descendants of enslaved people may unconsciously internalize stress, thereby living with significant negative emotions such as sadness, fearfulness, anxiety, anger, and hate. ${ }^{19}$ For some descendants of the enslaved, these harms include a damage to their "spirit," especially from the perspectives of African spirituality. ${ }^{20}$ For this reason, dehumanizing acts can be experienced as a spiritual harm, even though "spirit" might have provided solace and resilience, enabling some people to feel re-anchored in the experience of being fully human..$^{21}$

Third, trauma can be experienced as a rupture in the relational life of the descendants of the formerly enslaved, not only with the people who are from other groups, such as the offspring of enslavers, but also with the whole community. The antagonism can be extended to all who have benefited from transatlantic slavery, both short and long term. ${ }^{22}$ Hence, racism often manifests as a relational rift between black and white communities, and as such, it has become embedded in the fabric of contemporary western societies, as well as in the relationships between western societies and their former colonies in the Americas, Africa, and beyond.

Lastly, since the abolition of slavery, the harmful effects of the trauma have continued as institutional racism and structural violence. In contemporary western societies, typically, people of African descent experience poverty and social deprivation, as shown by their comparative lack of access to justice, quality education, healthcare, and housing. These are a form of structural injustice, ${ }^{23}$ and are part of the legacy of transatlantic slavery, sustained and amplified by the contemporary capitalist economic system. ${ }^{24}$

These four different kinds of harm are aspects of ill-being, manifested as pain, distress and suffering. ${ }^{25}$ They need to be addressed through the four-fold framework of collective healing mentioned earlier, which consists in: (a) historical, (b) personal (c) relational, and (d) structural dimensions, for which we will now provide a brief overview. ${ }^{26}$

Along the historical dimension, dehumanizing acts were usually performed, both directly and indirectly, by actors who sought profit from these acts. Because of this, healing

18 Kathy Sanders-Phillips et al., "Social Inequality and Racial Discrimination: Risk Factors for Health Disparities in Children of Color," Pediatrics 124, no. 3 (2009), 176-186; Council of Europe, "Combating Racism and Racial Discrimination Against People of African Descent in Europe," Round-table with human rights defenders organised by the Office of the Council of Europe Commissioner for Human Rights, Report (Strasbourg: Council of Europe, 2021).

19 Nathaniel Vincent Mohatt et al., "Review: Historical Trauma as Public Narrative: A Conceptual Review of How History Impacts Present-Day Health," Social Science \& Medicine 106, (2014), 128-136; Anderson J. Franklin et al., "Racism and Invisibility: Race-Related Stress, Emotional Abuse and Psychological Trauma for People of Color," Journal of Emotional Abuse 6, no. 2-3 (2006), 9-30.

${ }^{20}$ Jan Willis, "Spirituality and Resistance: How We Wake Up to Racism," Journal of Feminist Studies in Religion 36, no. 1 (2020), 85-97; Carla Hunter and Ma'at E. Lewis-Coles, "Coping with Racism: A Spirit-based Psychological Perspective," in The Psychology of Prejudice and Discrimination: Racism in America, ed. Jean Lau Chin (Westport: Praeger, 2004), 207-222; Jason R. Young, Rituals of Resistance: African Atlantic Religion in Kongo and the Lowcountry South in the Era of Slavery (Baton Rouge: Louisiana State University Press, 2007).

${ }^{21}$ Kia Bunsels Fu-Kiau, African Cosmology of the Bantu-Kongo: Principles of Life and Living (Brooklyn: Athekua Henrietta Press, 2001).

22 Farhad Dalal, Race, Colour and the Process of Racialization: New Perspectives from Group Analysis, Psychoanalysis and Sociology (New York: Brunner-Routledge, 2002).

${ }^{23}$ Robert L. Reece and Heather A. O'Connell, "How the Legacy of Slavery and Racial Composition Shape Public School Enrollment in the American South," Sociology of Race and Ethnicity 2, no. 1 (2016), 42-57.

${ }^{24}$ William K. Tabb, “Capitalism, Colonialism, and Racism," Review of Radical Political Economics 3, no. 3 (August 1971), 90-106.

${ }^{25}$ Mark Fisher proposes that these are also the symptoms of contemporary capitalist system. See Fisher, Capitalist Realism, 40.

26 This four-fold process does not map one for one onto the types of harm. It is an orthogonal classification. 
must involve a shared recognition of this history by not just those who have suffered, but more importantly, by the groups who carried out the violence and those who have benefitted from it. Likewise, it ought to include an acknowledgement of the widespread social damage resulting from the dehumanizing acts in the past and their continuing legacies. Museums, memorials, and commemorations provide public spaces for people to reach such recognition and acknowledgement. Political acts of public apology and asking for forgiveness can also contribute to healing. Likewise, institutional actions that attempt to rectify the wrongdoing through legal reforms, and reparations can further help heal the continuing trauma. ${ }^{27}$

In terms of the second dimension, namely the traumatic effects on individual people, it is important to recognize that trans-generationally transmitted trauma not only affects the descendants of the enslaved and those African communities from which the enslaved people were taken, but also the descendants of those who participated in and benefited materially from the acts of slavery, even if they are not consciously aware of such harm. ${ }^{28}$ Healing along this dimension will engage people from these different groups through sharing feelings, emotions and experiences, addressing the psycho-somatic trauma, and mutually supporting each other towards well-being.

With regard to the third dimension, the current relational harms of transatlantic slavery include contemporary racism, racially segregated relationships and colonialism manifested as the discrimination against Africans, Afro-descendant, and African diaspora around the world. This points to the imperative for people from diverse communities to come together to experience each other as persons and enrich a mutual feeling of being respected, in ways that shift the relational from degenerative to congenial and mutually affirming. ${ }^{29}$ Healing, in this sense, also requires creating spaces within which people do not experience themselves to be merely holders of pre-determined polarizing identities, such as victims vs. victimizers.

Concerning the fourth dimension, healing at the structural level, the continuation of historical dehumanization into the present depends partly on the systemic features of capitalist society that tend to instrumentalize and divide people. Such a society favors those who are wealthy at the expense of the poor, and ensures that those who are already marginalized remain vulnerable. ${ }^{30}$ In short, the western political economic system is fundamentally racist. This can severely hamper healing processes. It means that healing requires solidarity amongst the different groups in demanding and co-creating humanizing conditions for collective well-being. Given this solidarity, groups can engage in collaborative efforts towards advocating local and regional institutional reforms that aim to eradicate racist practices and attitudes.

In summary, this four-fold differentiation separates diverse facets of collective healing processes to address the following: historical dehumanization, traumas and harmful effects on persons, relational harms, and finally, the structural conditions that permit the continuation of transatlantic slavery's violent legacy.

\section{Collective Healing: Opportunities and Challenges}

A major point highlighted so far is that any healing endeavor must be directed at all four aspects, including acknowledging the acts of past wounding, alleviating present traumatic and harmful effects, restoring relationships caused by the harms, and addressing the structural causes of dehumanization. Although there are approaches aimed at collective healing, and despite some political gestures towards acknowledging historical and systemic dehumanization, most healing practices are restricted to grassroot efforts arising from the

\footnotetext{
${ }^{27}$ Angelique M. Davis, "Apologies, Reparations, and the Continuing Legacy of the European Slave Trade in the United States," Journal of Black Studies 45, no. 4 (2014), 271-286.

${ }^{28}$ Nell Irvin Painter, Creating Black Americans: African-American History and Its Meanings, 1619 to the Present (New York: Oxford University Press, 2006).

${ }^{29}$ Hübl and Avritt, Healing Collective Trauma; Volkan, Large-Group Psychology.

${ }^{30}$ Alvin N. Alvarez et al., The Cost of Racism for People of Color: Contextualizing Experiences of Discrimination (Washington, DC: American Psychological Association, 2016).
} 
communities that have long suffered racism and social injustice. How might we expand such efforts beyond these restrictions? How do these practices contribute to collective healing? How do they illustrate the opportunities and challenges that organizations are confronted with when engaging in collective healing? Let us examine these questions in light of the four-fold conceptual framework.

\section{Acknowledging Dehumanizing Histories}

Many people still do not recognize the connections between transatlantic slavery, capitalist exploitation, the racism in some contemporary western societies, and the political chaos of regions formerly colonized by European powers. ${ }^{31}$ However, there have been some attempts to open up dialogue about this history and its wide-spread legacy. Such an effort "starts with an honest conversation regarding the history of slavery, its legacy, and all of its ramifications throughout society today.... that leads to remedial actions for the conditions resulting from the continuing legacy of slavery." 32

Therefore, recognizing the history of dehumanization is key to societies' stepping onto constructive pathways towards accepting responsibilities and initiating healing. ${ }^{33}$ Such healing requires that global leaders publicly acknowledge the moral wrongs of transatlantic slavery, offer sincere apologies, and ask for forgiveness on behalf of the states or national governments who were involved in the historical dehumanizing acts. ${ }^{34}$ How politicians and governments respond to historical atrocities and injustices can truly make a difference to healing the exploited groups and their descendants. ${ }^{35}$ When sincerely offered and caringly phrased, a government's public apology can have the potential to condemn past moral wrongdoings, and express serious commitment to redressing past and present injustices. Furthermore, when a government publicly asks for forgiveness, it can do so implicitly on behalf of those groups who profited from the brutality and whose descendants continue to be privileged because of it, without imposing guilt or inviting resistance. Through public apology and political forgiveness, a government already assumes some responsibility for past atrocities and their enduring harmful legacy, and thereby, they can serve to shift blame from a purely personal level and avoid the tendency to blame victimized groups for their vulnerability.36

Research that evaluated 13 significant political apologies in the 20th century identified some key elements that might contribute to collective healing. Those pertinent to our discussion here are: expressing remorse; accepting moral offence; acknowledging harms, pains, and sufferings endured by the victim groups; asking for pardon and forgiveness; recognizing responsibility, and demonstrating commitment to reparation and reconciliation. ${ }^{37}$ However, political gestures that recognize the continued damage of past brutalities are few, and we will examine significant ones from those at city-level to those at state and national levels.

At city level, an important example is the Reconciliation Triangle, linking Benin (West Africa), Liverpool (UK), and Richmond, Virginia (USA), which opened the possibility of healing beyond conventional national lines. Following the 1998 apology issued by Richmond's mayor, Liverpool City Council made a similar apology for their role in the slave trade in 1999. Between

\footnotetext{
31 Stanford Cloud, Jr. "The Next Bold Step Toward Racial Healing and Reconciliation: Dealing with the Legacy of Slavery." Howard Law Journal 45, no. 1 (2001), 157-175. On page 167, Cloud highlights that "most Americans don't really know the history and its resulting legacy." The same statement applies to most contemporary western societies.

32 Cloud, The Next Bold Step, 167-168.

33 Jennifer Lind, Sorry States: Apologies in International Politics (Ithaca: Cornell University Press, 2008); Stephanie Wolfe, The Politics of Reparations and Apologies (New York: Springer, 2014).

${ }^{34}$ Craig W. Blatz et al., “Government Apologies for Historical Injustices,” Political Psychology 30, no. 2 (2009), 219-241; UNESCO, Healing the Wounds; Angelique. M. Davis, "Racial Reconciliation or Retreat? How Legislative Resolutions Apologizing for Slavery Promulgate White Supremacy," The Black Scholar 42, no.1 (2012), 37-48.

${ }^{35}$ Blatz, et al., Government Apologies.

36 Aaron Lazare, On Apology (New York: Oxford University Press, 2004).

37 Blatz, et al., Government Apologies.
} 
1999-2000, the President of Benin embarked on an international "tour of apology," and made a formal apology for Benin's role in selling fellow Africans into slavery, convening fellow slave trading countries and members of the African Diaspora. This apology was repeated in Richmond. In addition, reconciliation statues were erected in all three locations to mark these political acts. Another is the public apology from Mayor of Amsterdam, Femke Halsema, who acknowledged the city's role in the transatlantic trade of enslaved Africans. She not only recognized the city's part in past dehumanization, but also connected legacies of slavery to widespread racism in the city.

At state level, there is the example in the USA in which, between 2007 and 2009, a flurry of resolutions was passed across eight US States, as well as separately by the Federal Government and US Senate. Although no joint bill was passed, these resolutions were expressions of "profound regret" for the injustices of chattel slavery, and acknowledged their sustained perpetuation in current time. ${ }^{38}$ One further state (Delaware) followed suit in 2016, and called for recognition, remembrance, and reconciliation.

National leaders' gestures include former British Prime Minister Tony Blair's apology after his meeting with Ghanaian President John Agyekum Kufuor on March 14, 2007. Apart from apologizing for Britain's role in transatlantic slavery, Blair also praised the contributions of Black African and Caribbean communities in the UK today.

These examples show that formal apologies can place past atrocities directly in a public conversation. They acknowledge the acts of wounding, and more importantly, they legitimize this acknowledgement, and when combined with commitments to racial justice, they can have the potential to facilitate social and economic reforms. The question remains: How do they contribute to collective healing? Some writers have argued that acknowledging historical dehumanization, when accompanied by genuine atonement and reparation, can be regarded as an important starting point for collective healing, but only if it is grounded in acceptance and support from the harmed or victimized communities. ${ }^{39}$

A major challenge is that public apologies can be deceptive by giving the appearance of a commitment to reparation and reconciliation, but without any intention to take concrete actions to change the plight of those most affected.40 Whilst there are few cases of national governments making specific commitments for continued reparative actions, an institution that has taken a proactive and thoughtful approach to acting upon the commitment to reparation is Georgetown University. The historical dehumanizing act took place in 1838 when 272 enslaved men, women, and children were sold by Jesuit monks who in turn used the money to finance the University. As part of public reckoning and atoning, the University intentionally involved African American communities, including the direct descendants of the those who were sold in 1838. In addition, the University engaged current students in an open conversation who then voted to pay into a Reparation Fund aimed at financially supporting the descendants of the formerly enslaved people. According to the descendants who participated in this process, this level of engagement and caring has indeed contributed to healing. ${ }^{41}$

It is widely debated how reparations should be structured so that they can exemplify an acceptance of responsibility for historical wrongdoings, which at the same time can be accepted

\footnotetext{
38 Mark Medish and Daniel Lucich, "Congress Must Officially Apologize for Slavery Before America can Think About Reparations," Think, August 30, 2019, accessed March 26, 2021, https://www.nbcnews.com/think/opinion/ congress-must-officially-apologize-slavery-america-can-think-about-reparations-ncna1047561.

${ }^{39}$ Hiro Saito, "The Cultural Pragmatics of Political Apology," Cultural Sociology 10, no. 4 (2016), 448-465.

${ }^{40}$ Eric K. Yamamoto et al., "American Reparations Theory and Practice at the Crossroads," California Western Law Review 44 , no. 1 (2007), 1-85.

${ }^{41}$ David Collins et al. "Report of the Working Group on Slavery, Memory, and Reconciliation to the President of Georgetown University," June 3, 2016, accessed April 23, 2021, https://www.americamagazine.org/sites/default/ files/attachments/working group on slavery memory and reconciliation final report.pdf; Hannah Urtz and Lily Steinberg, "University Apologizes for Sale of 272," The Hoya, April 21, 2017, accessed April 3, 2021, https:// thehoya.com/university-apologizes-for-sale-of-272/.
} 
by the impacted communities as an active gesture towards making amends. 42 What should reparations consist in beyond monetary gestures? This question is further complicated when those directly involved in the dehumanizing acts are no longer alive, as in the cases of the slave trade and colonization of indigenous peoples. ${ }^{43}$

Around the world, scholars have proposed that reparations should be holistic. That is to say, in addition to financial compensation, there should be other ways to address the legacy of slavery, such as returning colonized land, safeguarding the right to land, offering better access to quality education and healthcare, and rectifying social policies that sustain institutional racism. ${ }^{44}$ Reparations and atonement signal responsibility to address the root causes of continued dehumanization. Therefore, reparations must go beyond symbolic apologies and include practical steps towards institutional reforms. In fact, all public apologies highlight the need for systemic transformation for, otherwise, structural violence will continue to perpetuate wounding. For instance, few have recognized that transatlantic slavery has a systemic root, namely an increasingly intensive capitalist economy in the countries concerned. We will return to this topic later.

Generally speaking, there is no consensus amongst scholars and practitioners regarding when and how public apologies and reparations might count towards healing. ${ }^{45}$ For example, do official apologies need to be accepted by the descendants of the enslaved for them to contribute to healing? Similarly, for political expressions of repentance and remorse to count towards healing, does it require the forgiveness of those communities suffering transgenerational trauma? ${ }^{46}$

Furthermore, the idea of the collective guilt of the communities who took part in and benefited from transatlantic slavery has been viewed as problematic, especially when the participation was indirect. For example, some writers regarded Germany's collective guilt at the end of WWII as confused. ${ }^{47}$ Whereas some who were personally responsible felt no remorse, many who were not directly involved, including the generations born after WWII, continue to feel shame. Collective guilt can obscure the accountability of those who were directly responsible for the atrocity.

Another challenge concerns the West's debt to Africa. Some may argue that, without the transatlantic trade of enslaved Africans, and further colonization by European countries, Africa would be an entirely different continent. Likewise, the West would not have prospered economically had it not been for the transatlantic slavery and colonization. Directly linked to this is the question about the interconnections between truth, justice, and healing. Are these separate processes or are they integral? When actors (such as individuals, corporations, cities, and governments) acknowledge their part in the transatlantic slave trade, does it require truthtelling and compensation in order to count towards justice and healing? ${ }^{48}$ Here lies a tension between justice as punishment (or retributive justice) and justice as returning to right

42 Ana Lucia Araujo, Reparations for Slavery and the Slave Trade: A Transnational and Comparative History (London: Bloomsbury Academic, 2017); Lily Gardner Feldman, Germany's Foreign Policy of Reconciliation: From Enmity to Amity (Lanham: Rowman \& Littlefield, 2012).

43 Maria Yellow Horse Brave Heart and Lemyra DeBruyn, "The American Indian Holocaust: Healing Historical Unresolved Grief," American Indian and Alaska Native Mental Health Research 8, no. 2 (1998), 56-76.

${ }^{44}$ Thomas Craemer, "Comparative Analysis of Reparations for the Holocaust and for the Transatlantic Slave Trade," The Review of Black Political Economy 45, no. 4 (December 2018), 299-324.

${ }^{45}$ Roy L. Brooks, Atonement and Forgiveness: A New Model for Black Reparations (Berkeley: University of California Press, 2004).

${ }^{46}$ Hannah Arendt, The Human Condition (Chicago: University of Chicago Press, 1958).

${ }^{47}$ Hannah Arendt, Eichmann in Jerusalem: A Report on the Banality of Evil (New York: Viking Press, 1963).

48 Kader Asmal et al., Reconciliation Through Truth: A Reckoning of Apartheids Criminal Governance (Cape Town: David Philip Publishers, 1994); Brandon Hamber and Steve Kibble, From Truth to Transformation: The Truth and Reconciliation Commission in South Africa (London: Catholic Institute for International Relations, 1999). 
relationship (or restorative justice), ${ }^{49}$ even if these are not necessarily mutually exclusive. However, in both cases, the immediate need to find ways to reconcile often means that structural causes are not addressed, even though ignoring structural violence perpetuates wounding.

When confronted with the details of transatlantic slavery, people of European descent can feel psychologically paralyzed to discuss this history in an open and honest way. ${ }^{50}$ To this end, grassroots movements, such as Coming to the Table (CTTT) Reparations Working Group, have attempted to advance public atonement by evoking the responsibilities of people and communities who benefited from the trade of enslaved Africans and slavery. Some religious organizations and corporations have joined such efforts, such as the Episcopal Church and the Southern Baptist Convention in the US, as well as the families who became wealthy in this manner.

However, focusing solely on individual culpability can ignore the institutional nature and the structural causes of dehumanization. Hence, systemic transformation must be integrated into the collective healing process. Public acknowledgement, political atonement, and material reparation require institutional reforms, such as revising laws and the development of socio-economic institutions that are not racist. ${ }^{51}$ In theory, collective healing requires social justice to be complete. ${ }^{52}$ Nevertheless, greater social justice practically requires more collective healing.

\section{Addressing Legacies of Slavery}

Dehumanization causes serious personal harm along several dimensions: being denied the opportunity to engage in valuable activities such as learning and work; feelings of anxiety, fear, anger and sadness; and being discriminated against and marginalized. ${ }^{33}$ Especially important is that persistent dehumanization can damage people's self-awareness or self-appreciation, one's sense of oneself as a whole human being of value. ${ }^{54}$ Historical acts of dehumanization can leave successive generations traumatized. The combination of this intergenerational trauma following enslavement and its enduring legacy, such as institutional racism, can cause social and psychological pathologies. Typically, social pathology includes high rates of suicide, domestic violence, and other social problems. Psychological pathology includes anxiety, depression, anger, and other mental health problems. ${ }^{55}$ These symptoms are particularly common amongst communities of African descent in contemporary societies affected by transatlantic slavery, such as Brazil, Colombia, the Caribbean, and the USA. Cultural trauma is more complex, and can include a lingering sense of alienation from one's own humanity, suffering in the spirit, as well as alienation. 56

Collective healing consists, in part, of liberating persons from these harmful effects. This requires recognizing the wounding as such rather than merely dealing with its symptoms.

\footnotetext{
${ }^{49}$ Morton Deutsch, "Justice and Conflict," in The Handbook of Conflict Resolution: Theory and Practice, ed. Peter Coleman et al. (San Francisco: John Wiley \& Sons, 2014), 29.

50 Rob Corcoran, Trustbuilding: An Honest Conversation on Race, Reconciliation, and Responsibility (Charlottesville: University of Virginia Press, 2010).

51 Randall Kennedy, Sellout: The Politics of Racial Betrayal, 1st ed. (New York: Pantheon Books, 2008).

52 Deutsch, Justice and Conflict.

53 Joy DeGruy, Post Traumatic Slave Syndrome: America's Legacy of Enduring Injury and Healing (Milwaukie: Uptone Press, 2017); Mia Smith Bynum et al., "Racism Experiences and Psychological Functioning in African American College Freshmen: Is Racial Socialization a Moderator?," Cultural Diversity and Ethnic Minority Psychology 13, no. 1 (2007), 64-71.

${ }^{54}$ Watts-Jones, Healing Internalized Racism.

${ }^{55}$ DeGruy, Post Traumatic Slave Syndrome.

56 Wade W. Nobles, "Shattered Consciousness, Fractured Identity: Black Psychology and the Restoration of the African Psyche," Journal of Black Psychology 39, no. 3 (2013), 232-242.
} 
We will examine a few significant psychotherapeutic practices developed to address the harrowing legacy of transatlantic slave trade and slavery.

Breaking silence about past dehumanizing acts is regarded as key to recognizing and subsequently addressing traumatic effects, diminishing suffering, and assuaging grief and other tormenting emotions. ${ }^{57}$ Safe public spaces and engagements to show the damage of past brutalities can contribute to healing, including memorial and burial sites, and museums, as well as history textbooks, and artistic outlets such as arts, music, films, literature, and theatre. ${ }^{58}$ The House of the Enslaved (Maison des Esclaves) and its Door of No Return on Gorée Island, Dakar, Senegal, Angolan National Museum of Slavery, International Slavery Museum in Liverpool, and National Museum of African American History and Culture in Washington DC are such examples. These help engender shared collective memories that de-silence suffering, ${ }^{59}$ and permit a recognition of the wide variety of relevant traumatic experiences. ${ }^{60}$ De-silencing can help put a human face on the often unspeakable agonies and hurts, and it is an important prelude to mourning as opposed to remaining in a state of numbness and disembodiment. ${ }^{61}$ Once memories are shared and pain and suffering are spoken about, there can be grieving and mourning for the prolonged losses and continued injustice. ${ }^{62}$ Memorialization further creates the opportunity and space for the collective working-through of trauma. 63

Although de-silencing has the potential to contribute to collective healing, there are challenges. ${ }^{64}$ For instance, trauma is multi-layered, and often memories do not distinguish between the different layers, such as the multifarious causes of historic wounding, intergenerational trauma from structural violence. Instead, they tend to be intermingled in an indiscernible bundle. ${ }^{65}$ Similarly, it is not readily evident what emphasis should be placed on the different factors in healing processes, especially with regard to de-silencing the historical legacy on the one hand, and trying to transcend it on the other. ${ }^{66}$ For this reason, activities to desilence, to acknowledge pain and trauma, and to commemorate the losses must be carried out in safe spaces in which people feel respected and cared for. Yet, it has been cautioned that, in advocating de-silencing, it is necessary to be vigilant so that the process does not perpetuate polarization and antagonism.

Another well-recognized approach is the active employment of therapeutic practices to address psychological social pathologies. Trauma can be manifested by individuals who have

${ }^{57}$ Ira Berlin et al., eds., Remembering Slavery (New York: The New Press, 1998); Ramona Beltrán and Stephanie Begun, "'It Is Medicine:' Narratives of Healing from the Aotearoa Digital Storytelling as Indigenous Media Project (ADSIMP)," Psychology \& Developing Societies 26, no. 2 (2014), 155-179; Susan V. Donaldson, "Telling Forgotten Stories of Slavery in the Postmodern South," The Southern Literary Journal 40, no. 2 (2008), 267-283; Mechelle N. Best, "'Freedom Footprints: the Barbados Story'-A Slavery Heritage Trail," Journal of Heritage Tourism 12, no. 5 (2017), 474-488.

58 Alvin O. Thompson, Confronting Slavery: Breaking Through the Corridors of Silence (St. Michael: Thompson Business Services, 2010); UNESCO, The Slave Route: Reconciling the Duty to Remember an Historical Truth (Paris: UNESCO, 2009), accessed December 13, 2021, https:/ / en.unesco.org/themes/fostering-rights-inclusion/slave-route\#racism; Lee Jolliffe, ed., Sugar Heritage and Tourism in Transition (Bristol: Channel View, 2012).

59 Araujo, Reparations for Slavery.

${ }^{60} \mathrm{Hübl}$ and Avritt, Healing Collective Trauma.

${ }^{61}$ Edward S. Casey, Remembering: A Phenomenological Study (Bloomington: Indiana University Press, 2009); Judith Butler, Precarious Life: The Powers of Mourning and Violence (London: Verso, 2006); Paul Gilroy, The Black Atlantic: Modernity and Double-Consciousness (Cambridge: Harvard University Press, 1993).

62 Justin Grinage, “Endless Mourning: Racial Melancholia, Black Grief, and the Transformative Possibilities for Racial Justice in Education," Harvard Educational Review 89, no. 2 (2019), 227-250.

${ }^{63}$ Laurence J. Gould, "Collective Working Through: The Role and Function of Memorialisation," Organisational and Social Dynamics 11, no. 1 (2011), 79-92.

${ }^{64}$ Catherine Hall, “Doing Reparatory History: Bringing 'Race' and Slavery Home,” Race E Class 60, no. 1 (2018), 3-21.

${ }^{65}$ Luis Urrieta, “Indigenous Reflections on Identity, Trauma, and Healing: Navigating Belonging and Power," Genealogy 3, no. 2 (2019), 26.

${ }^{66}$ Alan Rice, "Remembering Iconic, Marginalized and Forgotten Presences: Local, National and Transnational Memorial Sites in the Black Atlantic," Current Writing 16, no. 2 (2004), 71-92; Paul Gilroy, After Empire: Melancholia or Convivial Culture? (London: Routledge, 2004). 
not directly experienced the violence themselves. This includes the so-called "European psychosis," identified in research carried out in the Caribbean, a delusion that plagued the collective psyche of those who profited from enslavement and colonization, as well as the enslaved and colonized. ${ }^{67}$ This delusion was that people of whiter skins are superior, and those with darker skin were considered to be inferior and even sub-human. A European ideological fabrication, this delusion has been key in enabling one group of people to commodify, enslave, and brutalize another. Without healing and reconciliation, as a case study in Jamaica illustrates, many worldwide communities of African descent can feel in ways as if enslavement has continued until the present day, ${ }^{68}$ because on a daily basis, they experience psychological and social pathological symptoms. ${ }^{69}$

There are psychosocial approaches to overcoming this psychosis, especially in grassroot movements and community-based practices. One such approach is to focus on making sense of the trauma by recognizing one's own experiences of being traumatized and, at the same time, separating one's sense of oneself from that trauma and the associated experiences. This separation can enable a person to see that the somatic, psychological, and spiritual effects of the trauma are typical consequences of dehumanization. An example is a 12-week program entitled From the Cotton Fields to the Concrete Jungle which has successfully worked with groups of African American young men who reside in urban areas in the USA. ${ }^{70}$ It helps the young men to recognize how they are living out the traumatic effects in their behaviors, attitudes, and actions. This allows them to dissociate themselves from the experiences of trauma so that they are no longer defined by the trauma, thus stepping outside the psychosis.

Psychosocial approaches to healing ought to involve people of European descent, to whom the harmful legacies of slavery can equally apply, especially when some of who are struggling to transcend assumptions of superiority and feelings of fear, guilt, and shame. ${ }^{71}$ However, most people of European descent do not tend to identify their privilege in contemporary western societies, nor readily perceive the arrogance, indifference, and divisiveness that accompany such privilege as a harmful effect of slavery. This indicates that more work is required to characterize effective "white healing" practices.72 It also means that, in the context of transatlantic slavery, the healing of people of European descent should be a separate process from that of people of African and indigenous descent. Although white healing remains an emerging field, there are already some examples, such as Showing Up for Racial Justice (SURJ) and White Awake, that aim to promote awareness amongst people of European descent about the continuing wounds of slavery, and enable them to participate in collective liberation. ${ }^{73}$ In contemporary western societies, white healing is not common partly because white advantage is often denied. ${ }^{74}$ The dominant paradigm has created the norms, rules, and laws that define white people's benefits usually at the cost of black communities. ${ }^{75}$ Engaging

67 Frederick Hickling and Roger Gibson, "Philosophy and Epistemology of Caribbean Psychiatry," in Images of Psychiatry: The Caribbean, ed. Frederick Hickling and Eliot Sorel (Kingston: University of the West Indies, Mona, 2005), 75-108.

68 Samantha Longman-Mills et al., "The Psychological Trauma of Slavery: The Jamaican Case Study," Social and Economic Studies 68, no. 3-4 (2019), 79-101.

${ }^{69}$ Beltrán and Begun, It Is Medicine.

70 Jennifer Mullan-Gonzalez, "Slavery and the Intergenerational Transmission of Trauma in Inner City African American Male Youth: A Model Program-From the Cotton Fields to the Concrete Jungle," (PhD diss., California Institute of Integral Studies, 2012).

71 Thomson, Understanding Collective Healing.

72 Judy H. Katz, White Awareness: Handbook for Anti-Racism Training (Norman: University of Oklahoma Press, 1978).

73 Showing Up for Racial Justice (SURJ), (website), n.d., accessed March 12, 2021, https:// www.showingupforracialjustice.org/; White Awake. Waking Ourselves for the Benefit of All, (website), n.d., accessed date April 15, 2021, https:/ / whiteawake.org.

74 Toni Morrison, Playing in the Dark: Whiteness and the Literary Imagination (New York: Vintage, 1993).

${ }^{75}$ Layla F. Saad, Me and White Supremacy: How to Recognise Your Privilege, Combat Racism and Change the World (London: Quercus, 2020). 
white communities can help transcend the unconscious biases and negative emotions that prevent their active involvement in collective healing. This could be a liberation for both the white and black communities.

However, most societies, especially those in the Americas, adversely affected by the transatlantic slavery, are increasingly becoming mixed, ethnically, and racially. These multiracial and multi-ethnic societies include people who transcend or evade a simple black-vs.white racial characterization. Nevertheless, in countries such as Brazil, Colombia, and the USA, racial divides continue, with Afro-descendant communities suffering from racial inequality and discrimination that impacts all aspects of their economic and social life. The wealthier tend to be those of European descent, and the poorer, of African and indigenous descent. Therefore, the idea that therapeutic practices need to be applied to the European psychosis remains valid, even though its application needs to be culturally sensitive.

Other approaches to addressing legacies of slavery involve celebrating the value of African cultures. Initiatives of this kind include the UNESCO's International Jazz Day, Black Awareness Day in Brazil, Afro-Colombian Day, Black History Month in western societies, and the United Nations Decade of People of African Descent (2015-2024). Such celebrations of African cultures provide opportunities to emphasize how African cultures are already deeply embedded in communities worldwide and they can enable people of African descent to reconnect to their dignity, thus contributing to healing.

Psychosocial approaches to collective healing are riddled with risks and challenges. For instance, some activities may be re-traumatizing for those involved and deepen their experience of vulnerability by re-defining the participants as traumatized. ${ }^{76}$ Therapeutic approaches tend to reduce structural dehumanization to the category of a disease, which individualizes it. ${ }^{77}$ Processes that heal wounds will involve: identifying and contextualizing trauma; making sense of trauma and its causes and effects; and restoring awareness of one's wholeness and dignity.78 Healing is necessary to end racism and the cycles of racial violence.

\section{Collective Healing of Relations}

The effects of dehumanization include hostility, indifference, alienation, and mutual ignorance. Healing encompasses processes in which people develop better relationships that involve, as a minimum, a mutual recognition of each other as persons of equal worth. To address dehumanized relationships requires transcending antagonistic identity categories such as white-vs-black, perpetrator-vs-victim, and us-vs-them. Indeed, people harmed by the legacy of slavery may feel that their sense of themselves is defined by the fact that they are victims, especially in the context of institutional racism. ${ }^{79} \mathrm{In}$ this context, healing requires safe spaces in which participants can experience each other as persons, and become free of the antagonisms embedded in exclusionary ways of self-identifying. Such awareness paves the way towards selfidentifying that is more inclusive and has healing potential. It is important that such processes allow people to develop the capacity to become closer to others and transcend historical perceptions that propagate hostility.

There are plenty of examples of relational healing, especially in the US. The Kellogg Foundation's Racial Healing Circles and Truth, and their Racial Healing and Transformation initiatives are programs that recognize the structural influences on human relationships, and they problematize racial identity within these contexts. ${ }^{80}$ They provide safe spaces for people to explore their own and others' lives in the light of slavery and its legacies. Participants engage

\footnotetext{
76 Karen Brounéus, "Truth-Telling as Talking Cure? Insecurity and Retraumatization in the Rwandan Gacaca Courts," Security Dialogue 39, no. 1 (2008), 55-76.

77 Fisher, Capitalist Realism.

78 UNESCO, Healing the Wounds.

79 DeGruy, Post Traumatic Slave Syndrome.

80 Kellogg Foundation, Truth, Racial Healing and Transformation Implementation Guidebook (Battle Creek: Kellogg Foundation, 2016).
} 
with what ifs concerning wounding, reconciliation, and healing. A more widely integrated approach that nurtures more human relationships is the sharing of narratives that cross such intersections. ${ }^{81}$ This approach seeks to create "new authentic stories that honor the complexity of the past while forging a more equitable future." 82 Human narratives intersect at multiple levels: from individuals to groups and to cultures. In crossing these levels, story-sharing and highlights what people have in common and undermines dehumanization. ${ }^{83}$ This approach is especially relevant in the context of mixed-race groups in Europe and Latin America. Other healing programs tend to move beyond the idea race as the sole or main characterization of a person's identity.

However, the role of racial identities in relational healing is disputed. ${ }^{84}$ On the one hand, as an identity category, "race" necessarily accentuates divisions, partly because of the many sentiments attached such as humiliation, anger, guilt, arrogance, fear, and mistrust. On the other hand, racial division is a fact of history and healing requires working through and moving beyond such feelings. Indeed, in healing processes, the more racism is treated as an ideology, the more the healing process emphasizes people's reactions to racism, and the more it obscures racism as a structural phenomenon. Instead, it is more helpful to emphasize that racial injustice is reproduced and perpetuated by a system of economic priorities and political policies.

In dealing with dehumanized relationships, the process must address the needs of the wounded, and the responsibilities of those who have benefited from slavery. Some practitioners integrate an element of community-based restorative justice aimed at forgiveness and reconciliation, such as the Healing the Wounds of History programs. ${ }^{85}$ This element shifts the focus away from punishment to truth-telling and relational restoration. 86

The challenge here is that the concept of forgiveness has been understood varyingly. Often it is conceptualized as a conscious act of releasing feelings of resentment towards a person or a group who has harmed one, regardless of whether they deserve that forgiveness or not. ${ }^{87}$ For some, this should be unmediated and absolute. ${ }^{88}$ For others, forgiveness is relational in that forgiveness separates the agents of wrongdoing from their actions, and thus it can transcend the actors' personal guilt or remorse, and alter the ethical significance of the past, even purifying it. ${ }^{89}$ Thus, the concept of forgiveness invites many other questions. Does forgiveness condone structural violence? Is forgiveness compatible with justice? Processes of forgiveness may make those who have been hurt feel under pressure to forgive, which renders the process itself unjust. ${ }^{90}$ Indeed, such processes may seem to tolerate continued social

${ }^{81}$ Monisha Pasupathi et al., "Talking About It: Stories as Paths to Healing After Violence," Psychology of Violence 6, no. 1 (2016), 49-56.

82 Rachel D. Godsil and Brianna Goodale, Telling Our Own Story: The Role of Narrative in Racial Healing (Battle Creek: W. K. Kellogg Foundation/American Values Institute, 2013).

83 Robyn Fivush et al., "The Making of Autobiographical Memory: Intersections of Culture, Narratives and Identity," International Journal of Psychology 46, no. 5 (2011), 321-345.

84 Pilar N. Ossorio, "Myth and Mystification: The Science of Race and IQ," in Race and the Genetic Revolution, ed. Sheldon Krimsky and Kathleen Sloan (New York: Columbia University Press, 2015), 173-194.

85 Alexandra Asseily, Breaking the Cycles of Violence in Lebanon and Beyond (Brighton: Guerrand-Hermès Foundation for Peace Publishing, 2007); Scherto Gill, "Healing the Wounds of History: What Works, How and Why? A Critical Reflection on Four Pilot Workshops," Paper presented at 4th International Conference on Transgenerational Trauma, Amman, October 15, 2015.

86 Timothy H. Gailey, "Healing Circles and Restorative Justice: Learning from Non-Anglo American Traditions," Anthropology Now 7, no. 2 (2015), 1-7.

87 Scherto Gill, “Understanding Forgiveness: A Conceptual Map," Working Paper (Birmingham: Peace Charter of Forgiveness and Reconciliation, 2017).

${ }^{88}$ Jacques Derrida, On Cosmopolitanism and Forgiveness (London: Routledge, 2001).

89 Arendt, The Human Condition.

90 Vladimir Jankélévitch, “Should We Pardon Them?," trans. Ann Hobart, Critical Inquiry 22, no. 3 (1996), 552-567. 
injustices and make reconciliation more distant. This indicates that forgiveness cannot be a precondition or an expectation in the process of healing relationships. Nor is it the endpoint.

Other programs aimed at relational healing tend to stress trust-building, which requires good will to let go of suspicions and misgivings, and to show trust before one is trusted. ${ }^{91}$ Trust takes time because it is the fruit of relational processes. When employed as a healing approach, the activities of trust-building typically offer participants opportunities to listen to each other and to be heard; to show humility and vulnerability; to show care and genuine curiosity for others; and to have open and honest conversations about what is blocking good relations.

What relational healing programs cannot easily address is the fact that dehumanizing relations are a part of our lived realities, including in schools, hospitals, courts, workplaces, and on the street. These experiences are a result of the structural features that perpetuate the power dynamics shaping social relationships as such. This suggests that healing directed at relationships requires more than processes of reconciliation between individuals as representatives of social groups; it also requires institutional reform, which is integral to healing, and involves the commitment from communities to social justice.

\section{Collective Healing and Systemic Transformation}

Slavery contributed importantly to the wealth of the West. The economic prosperity of Western Europe and North America is largely due to systematic dehumanization, including slavery, genocide, and colonization. ${ }^{92}$ This has left many countries in Africa, the Caribbean, and South America materially impoverished and politically vulnerable. It has left many communities socially divided and emotionally wounded.

It is important to recognize that transatlantic slavery has its roots in economic exploitation which has engendered structural racism. Healing will require reflection on the historical origins of racist ideology, such as the commercial-scale enslavement of Africans for economic gain, during the birth of the current economic system. ${ }^{93}$ It is an inherent tendency of our economic system to treat all persons merely as commodities. Companies are interested primarily in the labor input of the people who work for them and in customers as a source of revenue. This means that the human richness of community life tends to get degraded to transaction-defined relationships between individuals who are otherwise indifferent to each other. The economic system tends to individualize and instrumentalize people, placing them into social spaces of competition and mistrust. In such a socio-economic context, relations between persons from different social groups are likely to be antagonistic, especially when neighborhoods are divided along the lines of race and wealth.

Over time, racist ideology became normalized when racial divides became integral to the social structure and to people's psyches. ${ }^{94}$ Such typification has been ingrained in groups' collective identities, resulting in these degenerative relationships that tend to define culture as seemingly resistant to transformation.

From a structural perspective, collective healing processes must highlight the historical role of profits-over-persons mentality and nurture an awareness of the equal intrinsic value of all humans. It is important to recognize that we are part of a system that tends to breed racism and that this is not merely a matter of personal choice. From this point, community groups might be moved to political action such as proposing reforms to local councils, as well as to national representatives.

Overcoming structural dehumanization requires that global leaders publicly disavow narratives that support the discrimination of people of African descent. Equally, it is necessary to change policies and practices that are unjust. Furthermore, we need to reimagine governance

\footnotetext{
91 Corcoran, Trustbuilding.

92 Carol Anderson, White Rage: The Unspoken Truth of Our Racial Divide (New York: Bloomsbury, 2016).

${ }^{93}$ Eric Eustace Williams, Capitalism and Slavery (Chapel Hill: University of North Carolina Press, 1994).

94 Judith Butler, Bodies That Matter (New York: Routledge, 1993); Reginald Horsman, Race and Manifest Destiny: The Origins of American Racial Anglo-Saxonism (Cambridge: Harvard University Press, 1981).
} 
processes and institutional practices so that it is no longer possible for human beings to be treated merely as means to economic gain. Abolishing the racist capitalist system requires a fundamental re-examination of the values that our societies are built upon, towards the recognition of the equal intrinsic value of all persons.

\section{Bibliography}

Akbar, Na'im. Breaking the Chains of Psychological Slavery. Tallahassee: Mind Productions \& Associates, 1996.

Allen, Robert C. The British Industrial Revolution in Global Perspective. Cambridge: Cambridge University Press, 2009.

Alvarez, Alvin N., Christopher T. H. Liang, and Helen A. Neville. The Cost of Racism for People of Color: Contextualizing Experiences of Discrimination. Washington, DC: American Psychological Association, 2016.

Anderson, Carol. White Rage: The Unspoken Truth of Our Racial Divide. New York: Bloomsbury, 2016.

Araujo, Ana Lucia. Reparations for Slavery and the Slave Trade: A Transnational and Comparative History. London: Bloomsbury Academic, 2017.

Arendt, Hannah. Eichmann in Jerusalem: A Report on the Banality of Evil. New York: Viking Press, 1963.

--------. The Human Condition. Chicago: The University of Chicago Press, 1958.

Asmal, Kader, Louise Asmal, and Ronald Suresh Roberts. Reconciliation Through Truth: A Reckoning of Apartheids Criminal Governance. Cape Town: David Philip Publishers, 1994.

Asseily, Alexandra. Breaking the Cycles of Violence in Lebanon and Beyond. Brighton: GuerrandHermès Foundation for Peace Publishing, 2007.

Baptist, Edward E. The Half Has Never Been Told: Slavery and the Making of American Capitalism. London: Hachette, 2016.

Beltrán, Ramona and Stephanie Begun. “'It Is Medicine:' Narratives of Healing from the Aotearoa Digital Storytelling as Indigenous Media Project (ADSIMP)." Psychology $\mathcal{E}$ Developing Societies 26, no. 2 (2014), 155-179.

Berlin, Ira, Marc Favreau, and Steven F. Miller, eds. Remembering Slavery. New York: The New Press, 1998.

Best, Mechelle N. "'Freedom Footprints: the Barbados Story'—A Slavery Heritage Trail," Journal of Heritage Tourism 12, no. 5 (2017), 474-488.

Blatz, Craig W., Karina Schumann, and Michael Ross. "Government Apologies for Historical Injustices." Political Psychology 30, no. 2 (2009), 219-241.

Brave Heart, Maria Yellow Horse, and Lemyra DeBruyn. "The American Indian Holocaust: Healing Historical Unresolved Grief." American Indian and Alaska Native Mental Health Research 8, no. 2 (1998), 56-76.

Brooks, Roy L. Atonement and Forgiveness: A New Model for Black Reparations. Berkeley: University of California Press, 2004.

Brounéus, Karen. "Truth-Telling as Talking Cure? Insecurity And Retraumatization in the Rwandan Gacaca Courts." Security Dialogue 39, no. 1 (2008), 55-76.

Butler, Judith. Bodies That Matter. New York: Routledge, 1993.

-------. Precarious Life: The Powers of Mourning and Violence. London: Verso, 2006.

Bynum, Mia Smith, Elvin Thomaseo Burton, and Candace Best. "Racism Experiences and Psychological Functioning in African American College Freshmen: Is Racial Socialization a Moderator?" Cultural Diversity and Ethnic Minority Psychology 13, no. 1 (2007), 64-71.

Casey, Edward S. Remembering: A Phenomenological Study. Bloomington: Indiana University Press, 2009.

Cloud, Sanford, Jr. "The Next Bold Step Toward Racial Healing and Reconciliation: Dealing with the Legacy of Slavery." Howard Law Journal 45, no. 1 (2001), 157-175. 
Collins, David et al. "Report of the Working Group on Slavery, Memory, and Reconciliation to the President of Georgetown University." June 3, 2016. Accessed April 23, 2020. http:// slavery.georgetown.edu/wp-content/uploads / 2016/08/GU-WGSMR-Report-Web.pdf.

Corcoran, Rob. Trustbuilding: An Honest Conversation on Race, Reconciliation, and Responsibility. Charlottesville: University of Virginia Press, 2010.

Council of Europe. "Combating Racism and Racial Discrimination Against People of African Descent in Europe." Round-table with human rights defenders organised by the Office of the Council of Europe Commissioner for Human Rights. Report. Strasbourg: Council of Europe, 2021.

Craemer, Thomas. "Comparative Analysis of Reparations for the Holocaust and for the Transatlantic Slave Trade." The Review of Black Political Economy 45, no. 4 (December 2018), 299-324.

Dalal, Farhad. Race, Colour and the Process of Racialization: New Perspectives from Group Analysis, Psychoanalysis and Sociology. New York: Brunner-Routledge, 2002.

Davis, Angelique. M. "Racial Reconciliation or Retreat? How Legislative Resolutions Apologizing for Slavery Promulgate White Supremacy." The Black Scholar 42, no. 1 (2012), 37-48.

"Apologies, Reparations, and the Continuing Legacy of the European Slave Trade in the United States." Journal of Black Studies 45, no. 4 (2014), 271-286.

DeGruy, Joy. Post Traumatic Slave Syndrome: America's Legacy of Enduring Injury and Healing. Milwaukie: Uptone Press, 2017.

Derrida, Jacques. On Cosmopolitanism and Forgiveness. London: Routledge, 2001.

Deutsch, Morton. "Justice and Conflict." In The Handbook of Conflict Resolution: Theory and Practice, edited by Peter Coleman, Morton Deutsch and Eric Marcus, 22-55. San Francisco: John Wiley \& Sons, 2014.

Deveau, Jean-Michel. "European Slave Trading in the Eighteenth Century." Diogenes 45, no. 179 (1997), 49-74.

Donaldson, Susan V. "Telling Forgotten Stories of Slavery in the Postmodern South." The Southern Literary Journal 40, no. 2 (2008), 267-283.

Drescher, Seymour. "Capitalism and Slavery After Fifty Years." Slavery \& Abolition 18, no. 3 (2008), 212-227.

Fisher, Mark. Capitalist Realism: Is There No Alternative?. Winchester: Zero Books, 2009.

Fivush, Robyn, Tilmann Habermas, Theordore E. A. Waters, and Widaad Zaman. "The Making of Autobiographical Memory: Intersections of Culture, Narratives and Identity." International Journal of Psychology 46, no. 5 (2011), 321-345.

Franklin, Anderson J., Nancy Boyd-Franklin, and Shalonda Kelly. "Racism and Invisibility: Race-Related Stress, Emotional Abuse and Psychological Trauma for People of Color." Journal of Emotional Abuse, 6, 2/3, (2006), 9-30

Fu-Kiau, Kia Bunsels. African Cosmology of the Bantu-Kongo: Principles of Life and Living. Brooklyn: Athekua Henrietta Press, 2001.

Gailey, Timothy H. "Healing Circles and Restorative Justice: Learning from Non-Anglo American Traditions." Anthropology Now 7, no. 2 (2015), 1-7.

Gates, Henry Louis Jr. Figures in Black: Words, Signs, and the "Racial" Self. Oxford: Oxford University Press, 1987.

Gill, Scherto. "Healing the Wounds of History: What Works, How and Why? A Critical Reflection on Four Pilot Workshops." Paper presented at 4th International Conference on Transgenerational Trauma, Amman, October 15, 2015.

"Understanding Forgiveness: A Conceptual Map." Working Paper, Birmingham: Peace Charter of Forgiveness and Reconciliation, 2017.

Gilroy, Paul. After Empire: Melancholia or Convivial Culture?. London: Routledge, 2004.

------. The Black Atlantic: Modernity and Double Consciousness. Cambridge: Harvard University Press, 1993. 
Godsil, Rachel D. and Brianna Goodale. Telling Our Own Story: The Role of Narrative in Racial Healing. Battle Creek: W. K. Kellogg Foundation / American Values Institute, 2013.

Goodman, Rachael D. “The Transgenerational Trauma and Resilience Genogram." Counselling Psychology Quarterly 26, no. 3-4 (2013), 386-405.

Gould, Laurence. "Collective Working Through: The Role and Function of Memorialisation." Organisational and Social Dynamics 11, no. 1 (2011), 79-92.

Grinage, Justin. "Endless Mourning: Racial Melancholia, Black Grief, and the Transformative Possibilities for Racial Justice in Education." Harvard Educational Review 89, no. 2 (2019), 227-250.

Hall, Catherine. "Doing Reparatory History: Bringing 'Race' and Slavery Home." Race \& Class 60, No. 1, (2018), 3-21.

Hamber, Brandon and Steve Kibble. From Truth to Transformation: The Truth and Reconciliation Commission in South Africa. London: Catholic Institute for International Relations, 1999.

Hickling, Frederick and Roger Gibson. "Philosophy and Epistemology of Caribbean Psychiatry." In Images of Psychiatry: The Caribbean, edited by Frederick Hickling and Eliot Sorel, 75-108. Kingston: University of the West Indies, Mona, 2005.

Horsman, Reginald. Race and Manifest Destiny: The Origins of American Racial Anglo-Saxonism. Cambridge: Harvard University Press, 1981.

Hübl, Thomas and Julie Jordan Avritt. Healing Collective Trauma: A Process for Integrating Our Intergenerational and Cultural Wounds. Boulder: Sounds True, 2020.

Hunter, Carla D. and Ma'at E. Lewis-Coles. "Coping with Racism: A Spirit-based Psychological Perspective." In The Psychology of Prejudice and Discrimination: Racism in America, edited by Jean Lau Chin, 207-222, Westport: Praeger, 2004.

Jankélévitch, Vladimir. "Should We Pardon Them?." Translated by Ann Hobart. Critical Inquiry 22, no. 3 (1996) 552-567.

Jolliffe, Lee, ed. Sugar Heritage and Tourism in Transition. Bristol: Channel View, 2012.

Katz, Judy H. White Awareness: A Handbook for Anti-Racism Training. Norman: University of Oklahoma Press, 1978.

Kellogg Foundation. Truth, Racial Healing and Transformation Implementation Guidebook. Battle Creek: Kellogg Foundation, 2016.

Kennedy, Randall. Sellout: The Politics of Racial Betrayal, 1st ed. New York: Pantheon Books, 2008.

Lazare, Aaron. On Apology. New York: Oxford University Press, 2004.

Lind, Jennifer. Sorry States: Apologies in International Politics. Ithaca: Cornell University Press, 2008.

Longman-Mills, Samantha, Carole Mitchell and Wendel Abel. "The Psychological Trauma of Slavery: The Jamaican Case Study." Social and Economic Studies 68, no. 3-4 (2019), 79-101

Lovejoy, Paul E. Transformations in Slavery: A History of Slavery in Africa, 3rd ed. Cambridge: Cambridge University Press, 2012.

Medish, Mark and Daniel Lucich. "Congress Must Officially Apologize for Slavery Before America Can Think About Reparations." Think, August 30, 2019. Accessed March 26, 2021. https://www.nbcnews.com/think/opinion/ congress-must-officially-apologizeslavery-america-can-think-about-reparations-ncna1047561.

Mohatt, Nathaniel Vincent, Azur B. Thompson, Nghi D. Thai, and Jacob Kraemer Tebes. "Review: Historical Trauma as Public Narrative: A Conceptual Review of How History Impacts Present-Day Health." Social Science \& Medicine 106, (2014), 128-136.

Morrison, Toni. Playing in the Dark: Whiteness and the Literary Imagination. New York: Vintage, 1993.

Mullan-Gonzalez, Jennifer. "Slavery and the Intergenerational Transmission of Trauma in Inner City African American Male Youth: A Model Program-From the Cotton Fields to the Concrete Jungle." PhD diss., California Institute of Integral Studies, 2012.

Nobles, Wade W. "Shattered Consciousness, Fractured Identity: Black Psychology and the Restoration of the African Psyche." Journal of Black Psychology 39, no. 3 (2013), 232-242. 
Ossorio, Pilar N. "Myth and Mystification: The Science of Race and IQ." In Race and the Genetic Revolution, edited by S. Krimsky, 173-194. New York: Columbia University Press, 2015.

Painter, Nell Irvin. Creating Black Americans: African-American History and Its Meanings, 1619 to the Present. New York: Oxford University Press, 2006.

Pasupathi, Monisha, Robyn Fivush, and Martha Hernandez-Martinez. "Talking About It: Stories as Paths to Healing After Violence." Psychology of Violence 6, no. 1 (2016), 49-56.

Reece, Robert L. and Heather A. O'Connell. "How the Legacy of Slavery and Racial Composition Shape Public School Enrollment in the American South." Sociology of Race and Ethnicity 2, no, 1 (2016), 42-57.

Rice, Alan. "Remembering Iconic, Marginalized and Forgotten Presences: Local, National and Transnational Memorial Sites in the Black Atlantic." Current Writing 16, no. 2 (2004), 7192.

Saad, Layla F. Me and White Supremacy: How to Recognise Your Privilege, Combat Racism and Change the World. London: Quercus, 2020.

Saito, Hiro. "The Cultural Pragmatics of Political Apology." Cultural Sociology 10, no. 4 (2016), 448-465.

Sanders-Phillips, Kathy, Beverlyn Settles-Reaves, Doren Walker, and Janeese Brownlow. "Social Inequality and Racial Discrimination: Risk Factors for Health Disparities in Children of Color." Pediatrics 124, no. 3 (2009), 176-186.

Stelzner, Mark. “Slavery and Capitalism." Labor History 61, no. 3-4 (2020), 335-347.

Tabb, William K. "Capitalism, Colonialism, and Racism." Review of Radical Political Economics 3, no. 3 (August 1971), 90-106.

Thompson, Alvin O. Confronting Slavery: Breaking Through the Corridors of Silence. St. Michael: Thompson Business Services, 2010.

Thomson, Garrett, Scherto Gill, and Ivor Goodson. Happiness, Flourishing and the Good Life: A Transformative Vision of Human Well-Being. London: Routledge, 2020.

UNESCO. Healing the Wounds of Slave Trade and Slavery. Approaches and Practices: A Desk Review. Brighton: The UNESCO Slave Route Project / GHFP Research Institute, 2021.

. The Slave Route: Reconciling the Duty to Remember an Historical Truth (Paris: UNESCO, 2009). Accessed December 13, 2021. https://en.unesco.org/themes/fostering-rightsinclusion/slave-route\# racism.

Urrieta, Luis. "Indigenous Reflections on Identity, Trauma, and Healing: Navigating Belonging and Power." Genealogy 3, no. 2 (2019), 26.

Urtz, Hannah, and Lily Steinberg. "University Apologizes for Sale of 272." The Hoya, April 21, 2017. Accessed April 3, 2021. https://thehoya.com/university-apologizes-for-saleof-272/.

Volkan, Vamik D. Large-Group Psychology: Racism, Societal Divisions, Narcissistic Leaders and Who We Are Now. Oxfordshire: Phoenix, 2020.

Watts-Jones, Dee. "Healing Internalized Racism: The Role of a Within-Group Sanctuary Among People of African Descent." Family Process 41, no. 4 (2002), 591-601.

Williams, Eric Eustace. Capitalism and Slavery. Chapel Hill: University of North Carolina Press, 1994.

Willis, Jan. "Spirituality and Resistance: How We Wake Up to Racism." Journal of Feminist Studies in Religion 36, no. 1 (2020), 85-97.

Wolfe, Stephanie. The Politics of Reparations and Apologies. New York: Springer, 2014.

Yamamoto, Eric K., Sandra Hye Yun Kim, and Abigail M. Holden. "American Reparations Theory at the Crossroads." California Western Law Review 44, no. 1 (2007), 1-85.

Young, Jason R. Rituals of Resistance: African Atlantic Religion in Kongo and the Lowcountry South in the Era of Slavery. Baton Rouge: Louisiana State University Press, 2007. 